\title{
THE EFFECT OF FINANCIAL LITERACY AND ACCOUNTING LITERACY TO ENTREPRENEURIAL INTENTION USING THEORY OF PLANNED BEHAVIOR MODEL IN STIE SUTAATMADJA ACCOUNTING STUDENTS
}

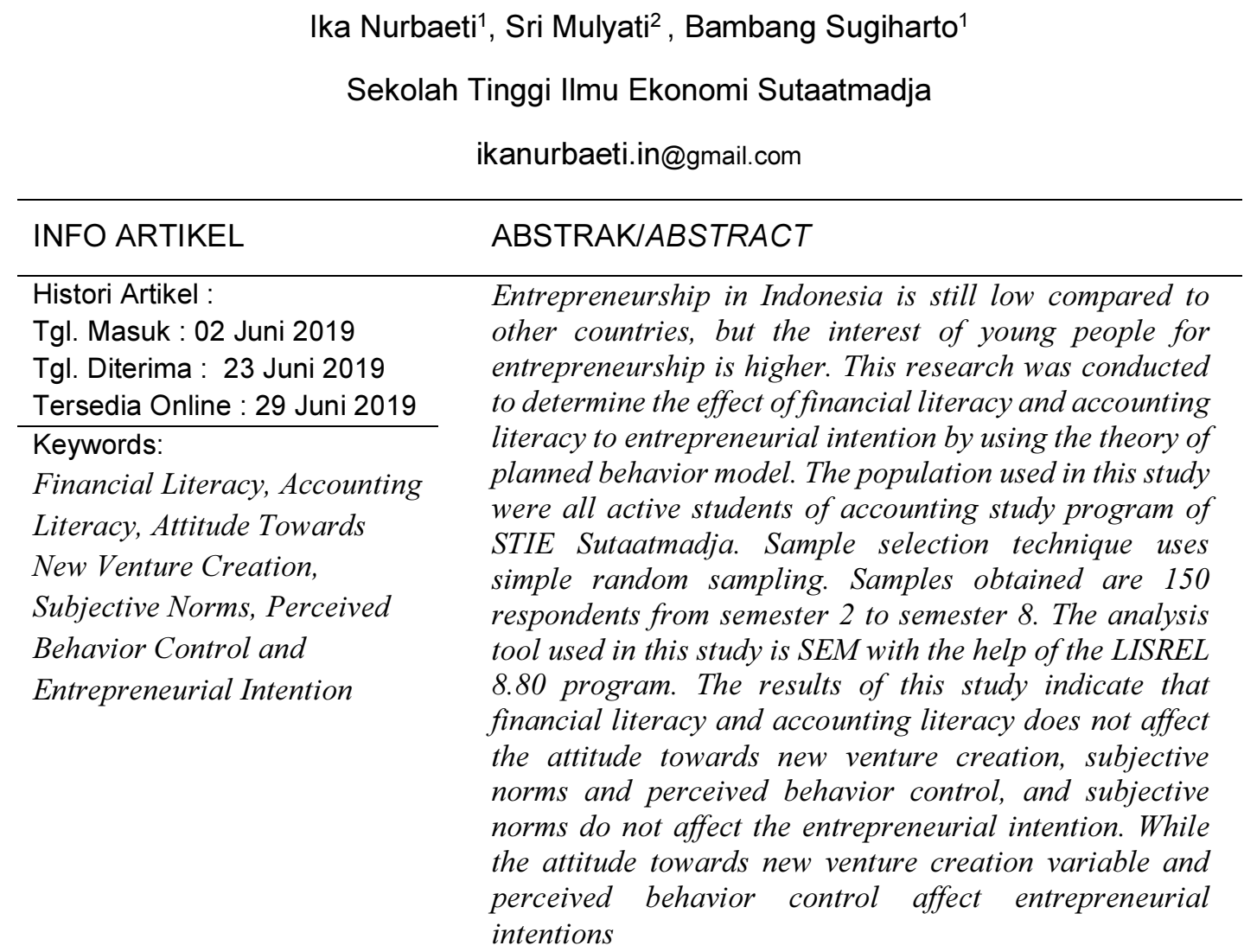

\section{PENDAHULUAN}

\section{PENDAHULUAN}

Indonesia saat ini masih menghadapi persoalan mengenai pengangguran. Hal ini didukung oleh pernyataan dari ketua STIE Nobel yaitu Mashur Razak selaku pemateri dalam suatu acara mengatakan bahwa : "Salah satu persoalan yang dihadapi bangsa Indonesia saat ini adalah masih tingginya angka pengangguran, termasuk pengangguran terdidik." (edukasi.rakyatku.com, 2018). Pengangguran terdidik merupakan kekurang selarasan antara perencanaan pembangunan pendidikan dengan perkembangan lapangan kerja (Sari, 2013). Pengangguran terdidik terjadi disebabkan oleh para lulusan yang hanya ingin mencari pekerjaan bukan membuka lapangan pekerjaan seperti menjadi seorang wirausaha. Wirausaha merupakan cara efektif untuk mengatasi ketimpangan antara angkatan kerja dengan lapangan pekerjaan yang tersedia (Wahyono et al, 2015).

Menurut Endang (2012) : "Wirausaha (entrepreneur) adalah orang yang berjiwa berani mengambil resiko untuk membuka usaha dalam berbagai kesempatan." Berdasarkan 
data Bank Dunia, jumlah wirausaha (entrepreneur) di Indonesia baru mencapai 3,3\% populasi. Jumlah itu masih kalah dibandingkan Thailand, Malaysia, apalagi Singapura (Pikiran Rakyat, 2017). Akan tetapi meskipun jumlah wirausaha di Indonesia masih rendah, minat generasi muda untuk berwirausaha meningkat seperti yang dikatakan oleh Kepala Staf Kepresidenan Teten Masduki dalam (Pikiran Rakyat, 2017) : "Kendati jumlah entrepreneur Indonesia masih sedikit, tapi minat anak muda terhadap wirausaha semakin tinggi." Kepala Career Center ITB, Bambang Setia Budi mengatakan dalam republika.co.id (2017) : "Saat ini berwirausaha di kalangan generasi muda menjadi sebuah pilihan yang bagus. Oleh karena itu pihaknya memfasilitasi mahasiswa yang ingin berwirausaha dan /fresh graduate yang tengah mencari pekerjaan atau pematangan." Dalam hal ini menandakan bahwa peran perguruan tinggi sangat penting dalam mendorong terciptanya wirausaha pada generasi muda, seperti halnya STIE Sutaatmadja (STIESA).

STIESA adalah perguruan tinggi lokal dengan wawasan global, berkarakter wirausaha. STIESA mempunyai berbagai program yang salah satunya untuk mendorong terciptanya wirausaha pada generasi muda seperti diadakannya event Bazaar tahunan. Selain itu juga di STIESA terdapat mata kuliah kewirausahaan. Hal ini menjadi bekal atau gambaran bagi mahasiswa mengenai berwirausaha. Selain itu juga ada beberapa mahasiswa yang melakukan usaha seperti berdagang/berjualan makanan, kosmetik, pulsa dan lain sebagainya.
STIESA menyadari akan pentingnya dorongan perguruan tinggi untuk menciptakan wirausaha baru dikalangan mahasiswa. Kepala Career Center ITB, Bambang Setia Budi mengatakan dalam republika.co.id (2017) bahwa : "Mereka yang memiliki pendidikan tinggi semestinya akan berpeluang lebih sukses dalam berwirausaha, ketimbang mereka yang tidak. Karena mereka yang berpendidikan memiliki wawasan yang lebih luas, kecepatan belajar, kemampuan membaca peluang, dan pikiran yang terbuka, yang semuanya dilatih sejak mahasiswa." Bagi seorang calon wirausaha penting untuk mengetahui faktor apa saja yang dapat mendukung dirintisnya sebuah usaha baru agar setiap kemampuan yang dapat menunjang bisa lebih dikembangkan dan semua sifat dan perilaku yang bisa menghambat dapat diminimalisir. Salah satu faktor yang diduga kuat mempengaruhi seseorang dalam merintis sebuah usaha adalah niat untuk berwirausaha (Nurfaizana dan Andayani, 2017).

\section{Niat} berwirausaha (Entrepreneurial Intention) merupakan bentuk kepercayaan diri seseorang yang berniat untuk mendirikan usaha bisnis baru dan secara sadar akan dilakukan dimasa depan (Thompson, 2009). Niat berwirausaha mencerminkan komitmen seseorang untuk memulai usaha baru dan merupakan isu sentral yang perlu diperhatikan dalam memahami proses kewirausahaan pendirian usaha baru (Walipah dan Naim, 2016). Semakin besar niat berwirausaha seseorang maka semakin besar kemungkinan untuk mencapai tujuan usahanya (Deri et al, 2016). Dalam mencapai tujuan sebuah usaha tidaklah mudah salah 
satunya harus mampu mengatur keuangannya. Salah satu cara mengatur keuangannya yaitu dengan literasi keuangan.

Literasi keuangan merupakan kemampuan untuk mengambil keputusan yang efektif dalam mengenai penggunaan keuangan saat ini dan pengelolaan keuangan masa depan (Basu, 2005:2; Nyamute dan Maina 2010) dalam (Rahayu dan Musdholifah, 2017). Menurut Oseifuah (2010) pentingnya literasi keuangan tidak dapat diremehkan, karena orang yang buta huruf secara finansial mungkin tidak dapat menganggarkan secara tepat untuk memenuhi pengeluaran, tidak dapat mengidentifikasi produk atau layanan keuangan yang memenuhi kebutuhannya, tidak yakin bagaimana cara mendapatkan dan menilai keuangan secara independen. Dalam berwirausaha sangat penting memiliki literasi keuangan yang baik karena selain untuk mengidentifikasi sumber dana juga diharapkan dapat mengelola keuangan untuk proses bisnis yang suskes (Singhry dan Bogoro, 2016). Dengan memiliki literasi keuangan yang baik juga dapat mempermudah akses ke lembaga keuangan, apalagi jika didukung dengan literasi akuntansi.

Salah satu masalah terbesar yang menyebabkan masyarakat tidak memiliki akses terhadap jasa perbankan adalah tidak adanya catatan keuangan dari kegiatan usaha mereka (Setiono, 2017). Ini menandakan bahwa tingkat literasi akuntansi masih rendah. Jika seseorang tidak memiliki catatan keuangan maka perbankan tidak akan memberikan pinjaman atau kredit. Hal ini akan berdampak terhadap usaha yang akan dijalankan. Carnes \& Hedin (1999) dalam Elson dkk (2013) melihat literasi akuntansi sama pentingnya bagi mereka yang akan sukses dalam bisnis. Sedangkan menurut IAI literasi akuntansi sangat penting di kalangan entitas, dalam rangka meningkatkan kualitas laporan keuangan entitas di masa depan. Dalam hal ini menandakan bahwa untuk seorang wirausaha alangkah baiknya jika memiliki tingkat literasi akuntansi yang baik dalam membangun dan menjalankan usahanya.

Beberapa penelitian sebelumnya mengenai literasi keuangan terhadap niat berwirausaha adalah dengan penerapan model Theory of Planned Behavior (TPB). TPB merupakan pengembangan lebih lanjut dari Theory of Reasoned Action (TRA) yang dicetuskan oleh Ajzen (Jogiyanto, 2007) dalam Sumaryono (2016). Menurut Ajzen (1991) : "Faktor utama TPB adalah niat individu untuk melakukan perilaku tertentu." Niat diasumsikan sebagai faktor motivasi yang menentukan perilaku seseorang. Dalam Sumaryono (2016) TRA mengusulkan bahwa : "Niat berperilaku adalah suatu fungsi dari sikap (attitude) dan norma subjektif (subjective norm) terhadap perilaku." Ajzen mengembangkan teori TPB dengan menambahkan konstruk yang belum ada di TRA yaitu persepsi kontrol perilaku (perceived behavioral control).

Melihat fakta tentang literasi keuangan dengan niat berwirausaha dan dihubungkan dengan penelitian yang dilakukan oleh Singhry dan Bogoro (2016) dengan hasil bahwa literasi keuangan memiliki hubungan yang signifikan dengan attitude towards new venture creation, subjective norms serta perceived 
behavior control. Kemudian hasil selanjutnya bahwa attitude towards new venture creation, subjective norms serta perceived behavior control memiliki hubungan yang signifikan terhadap graduate entrepreneurial intention. Kemudian penelitian mengenai literasi keuangan dan literasi akuntansi dilakukan oleh Trombetta (2016) dengan hasil bahwa rendahnya tingkat literasi akuntansi dan keuangan ditemukan pada bisnis yang telah lama beroperasi.

Penelitian ini berbeda dengan penelitian sebelumnya karena akan menggunakan variabel literasi akuntansi, mengingat literasi akuntansi juga sama pentingnya dengan literasi keuangan untuk calon wirausaha. Tujuan dari penelitian ini yaitu untuk mengetahui pengaruh literasi keuangan dan literasi akuntansi terhadap niat berwirausaha dengan menggunakan model theory of planned behavior pada mahasiswa akuntansi STIE Sutaatmadja. Dugaan sementara penelitian adalah literasi keuangan dan literasi akuntansi berpengaruh terhadap sikap pada penciptaan usaha baru, norma subjektif, dan persepsi kontrol perilaku. Kemudian sikap pada peciptaan usaha baru, norma subjektif, persepsi kontrol perilaku berpengaruh terhadap niat berwirausaha.

Jenis data dalam penelitian ini yaitu data kuantitatif dengan sumber data primer dan teknik pengumpulan data menggunakan kuesioner. Teknik sampling mengunakan simple random sampling. Hasil penelitian ini menunjukkan bahwa variabel literasi keuangan dan literasi akuntansi tidak berpengaruh terhadap sikap pada penciptaan usaha baru, norma subjektif, dan persepsi kontrol perilaku, kemudian sikap pada penciptaan usaha baru, dan persepsi kontrol perilaku berpengaruh terhadap niat berwirausaha, sedangkan norma subjektif tidak berpengaruh terhadap niat berwiausaha. Dengan penelitian ini diharapkan bagi mahasiswa yang memiliki niat berwirausaha dapat memiliki tingkat literasi keuangan yang baik karena sangat penting bagi kita untuk kesejahteraan di masa depan serta alangkah baiknya jika setiap individu mampu mengelola sumber dana yang didapat dan diharapkan dapat memiliki tingkat literasi akuntansi yang baik juga agar pencatatan laporan bisnisnya semakin baik dan dimudahkan dalam akses terhadap lembaga keuangan.

\section{KERANGKA TEORITIS DAN PENGEMBANGAN HIPOTESIS}

Teori yang digunakan dalam penelitian ini adalah Theory of Planned Behavior (TPB). Teori ini awal mulanya bernama theory of reasoned action (TRA), kemudian dikembangkan lagi oleh Icek Ajzen dan beganti menjadi theory of planned behavior (TPB). Ajzen

mengembangkan teori TPB dengan menambahkan konstruk yang belum ada di TRA yaitu persepsi kontrol perilaku (perceived behavioral contro/). TPB menyatakan bahwa selain sikap dan norma subjektif, seseorang juga mempertimbangkan kontrol perilaku yang dirasakan yaitu kemampuan mereka untuk melakukan tindakan tersebut (Sumaryono, 2016). Seperti dalam TRA yang sebenarnya, faktor utama TPB adalah niat individu untuk melakukan perilaku tertentu (Ajzen, 1991). 


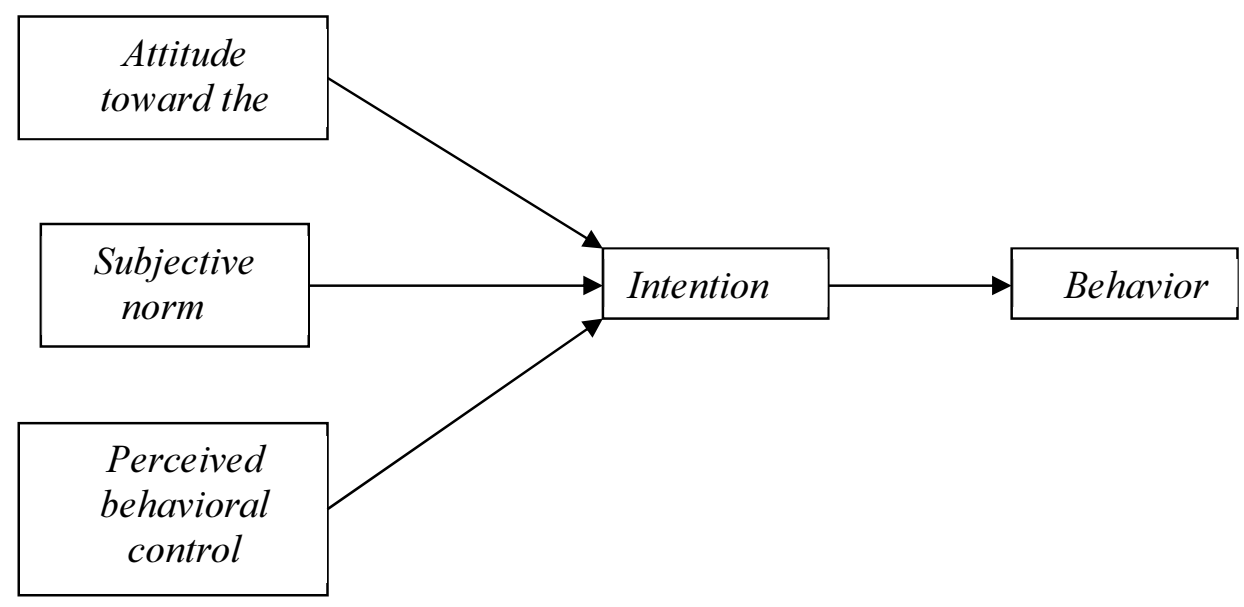

Kemudian niat merupakan perkiraan seseorang mengenai seberapa besar kemungkinan dirinya untuk melakukan suatu tindakan tertentu (Sukmaningrum dan Rahardjo, 2017). Ajzen (2001) theory of planned behavior menyebutkan bahwa intensi (niat) adalah fungsi dari tiga determinan dasar, yaitu:

1. Sikap berperilaku (attitude toward the behavior).

Ajzen (1991) sikap pribadi menjelaskan seberapa besar seseorang bermaksud untuk melakukan perilaku tersebut. Sikap merupakan suatu disposisi untuk merespon secara positif atau negatif perilaku tertentu. Sikap terhadap perilaku ditentukan oleh kombinasi antara keyakinan perilaku dan evaluasi hasil. Keyakinan perilaku adalah keyakinan individu mengenai konsekuensi positif atau negatif dari perilaku tertentu, sedangkan evaluasi hasil merupakan evaluasi individu terhadap konsekuensi yang didapatkan dari suatu perilaku (Ajzen, 1991).

2. Norma subjektif (subjective norm). Ajzen (1991) norma subjektif menjelaskan bagaimana pendapat orang-orang sekitar dapat mempengaruhi niat untuk melakukan perilaku tertentu.
3. Persepsi kontrol perilaku (perceived behavioral control).

Kontrol perilaku yang dirasakan mengenai kemudahan dan/atau kesulitan untuk melakukan perilaku tertentu (Ajzen, 1991).

Ajzen (1985) sikap terhadap perilaku, norma subjektif, dan persepsi kontrol perilaku mengarah pada pembentukan niat perilaku. Sebagai aturan umum, semakin baik sikap dan norma subyektif, dan semakin besar kontrol yang dirasakan, semakin kuat keinginan seseorang untuk melakukan perilaku yang bersangkutan.

\section{Kerangka Pemikiran dan Hipotesis}

Berwirausaha menjadi salah satu hal yang penting karena dengan berwirausaha, seseorang akan membuka lapangan pekerjaan bagi orang lain sehingga akan mengurangi pengangguran yang salah satunya yaitu pengangguran terdidik dimana setiap tahunnya selalu bertambah. Maka dari itu menururt Azwar (2013) mahasiswa yang merupakan calon lulusan perguruan tinggi perlu didorong dan ditumbuhkan niat mereka untuk berwirausaha (interpreneurial intention) karena menurut Nurfaizana dan Andayani (2017) : "Salah satu 
faktor yang diduga kuat mempengaruhi sesorang dalam merintis sebuah usaha adalah niat untuk berwirausaha." Peran perguruan tinggi merupakan salah satu hal yang penting dalam mendorong atau memperkuat niat mahasiswa untuk berwirausaha. Niat berwirausaha merupakan suatu kebulatan tekad untuk melakukan wirausaha dengan tujuan tertentu yang dimiliki oleh individu (Sukmaningrum dan Rahardjo, 2017). Untuk menjadi seorang wirausaha tidaklah mudah, karena banyak hal yang harus diperhatikan seperti halnya proses bagaimana pengelolaan keuangan bisnis yang baik dan bagaimana pencatatan hingga pelaporan keuangannya. Dengan demikian diperlukan tingkat literasi keuangan dan literasi akuntansi yang baik bagi setiap pelaku usaha. Dahmen dan Rodriguez (2014) juga menyatakan bahwa: "Pentingnya pemilik usaha memahami pengetahuan keuangan guna memiliki kinerja perusahaan yang lebih bagus." Untuk melakukan penelitian ini peneliti menggunakan model theory of planned behavior (TPB). TPB merupakan suatu teori untuk memprediksi niat sesorang untuk melakukan perilaku tertentu.

\section{Pengaruh Literasi Keuangan terhadap Sikap pada Penciptaan Usaha Baru}

Literasi keuangan didefinisikan sebagai kecerdasan atau kemampuan seseorang dalam mengelola keuangannya (Laily, 2016). Sikap terhadap perilaku mengacu pada sejauhmana seseorang memiliki evaluasi yang mendukung atau tidak mendukung atau penilaian terhadap perilaku yang bersangkutan (Ajzen, 1991). Singhry dan Bogoro (2016) menunjukkan bahwa semakin tinggi tingkat literasi keuangan, semakin besar kecenderungan untuk menciptakan usaha baru. Berdasarkan uraian di atas maka hipotesis dalam penelitian ini adalah :

$\mathrm{H} 1$ : Literasi keuangan berpengaruh terhadap sikap pada penciptaan usaha baru

\section{Pengaruh Sikap pada Penciptaan Usaha Baru terhadap Niat Berwirausaha}

Sikap terhadap perilaku mengacu pada sejauhmana seseorang memiliki evaluasi yang mendukung atau tidak mendukung atau penilaian terhadap perilaku yang bersangkutan (Ajzen, 1991). Niat berwirausaha dapat didefinisikan sebagai keinginan atau tekad individu untuk memulai bisnis baru untuk mengeksploitasi peluang dan risiko bisnis melalui pembelajaran kewiraswastaan (Utami, 2017). Munculnya niat berwirausaha didasarkan dari sikap seseorang untuk terjun memulai usaha baru (Bustarosa, 2018). Berdasarkan uraian di atas maka hipotesis dalam penelitian ini adalah :

H2: Sikap pada penciptaan usaha baru berpengaruh terhadap niat berwirausaha

\section{Pengaruh Literasi Keuangan terhadap Norma Subjektif}

Literasi keuangan didefinisikan sebagai kecerdasan atau kemampuan seseorang dalam mengelola keuangannya (Laily, 2016). Norma subjektif adalah keyakinan individu 
untuk mematuhi atau memenuhi saran atau masukan yang berasal dari orangorang sekitar untuk turut dalam kegiatan berwirausaha (Sukmaningrum dan Rahardjo, 2017). Penelitian sebelumnya oleh Singrhy dan Bogoro (2016) mengemukakan bahwa ada hubungan yang signifikan antara literasi keuangan dan norma subjektif. Berdasarkan uraian di atas maka hipotesis dalam penelitian ini adalah :

H3 : Literasi keuangan berpengaruh terhadap norma subjektif.

\section{Pengaruh Norma Subjektif terhadap Niat Berwirausaha}

Norma subjektif adalah keyakinan individu untuk mematuhi atau memenuhi saran atau masukan yang berasal dari orang-orang sekitar untuk turut dalam kegiatan berwirausaha (Sukmaningrum dan Rahardjo, 2017). Niat berwirausaha dapat didefinisikan sebagai keinginan atau tekad individu untuk memulai bisnis baru untuk mengeksploitasi peluang dan risiko bisnis melalui pembelajaran kewiraswastaan (Utami, 2017). Penelitian sebelumnya mengenai norma subjektif dilakukan oleh Singrhy dan Bogoro (2016) menunjukkan bahwa norma subjektif berhubungan secara signifikan dengan graduated entrepreneurial intention. Berdasarkan uraian di atas maka hipotesis dalam penelitian ini adalah:

H4 : Norma subjektif berpengaruh terhadap niat berwirausaha.

\section{Pengaruh Literasi Keuangan terhadap Persepsi Kontrol Perilaku}

Literasi keuangan didefinisikan sebagai kecerdasan atau kemampuan seseorang dalam mengelola keuangannya (Laily, 2016). Persepsi kontrol perilaku (perceived behavioral control) adalah kontrol perilaku yang dirasakan mengenai kemudahan dan/atau kesulitan untuk melakukan perilaku tertentu (Ajzen, 1991). Penelitian sebelumnya mengenai literasi keuangan dilakukan oleh Singrhy dan Bogoro (2016) menunjukkan hubungan positif antara literasi keuangan dan persepsi kontrol perilaku (perceived behavioral control). Berdasarkan uraian di atas maka hipotesis dalam penelitian ini adalah :

H5 : Literasi keuangan berpengaruh terhadap persepsi kontrol perilaku

\section{Pengaruh Persepsi Kontrol Periaku terhadap Niat Berwirausaha}

Persepsi kontrol perilaku (perceived behavioral control) adalah kontrol perilaku yang dirasakan mengenai kemudahan dan/atau kesulitan untuk melakukan perilaku tertentu (Ajzen, 1991). Niat berwirausaha dapat didefinisikan sebagai keinginan atau tekad individu untuk memulai bisnis baru untuk mengeksploitasi peluang dan risiko bisnis melalui pembelajaran kewiraswastaan (Utami, 2017). Penelitian sebelumnya mengenai hal ini dilakukan oleh Singrhy dan Bogoro (2016) mengemukakan bahwa perceived behavioral control memiliki hubungan secara positif dan signifikan dengan graduated entrepreneurial intention. Berdasarkan uraian di atas maka hipotesis dalam penelitian ini adalah : 
H6 : Persepsi kontrol perilaku berpengaruh terhadap niat berwirausaha

\section{Pengaruh Literasi Akuntansi terhadap Sikap pada Penciptaan Usaha Baru}

Literasi akuntansi merupakan pemahaman dalam menghasilkan laporan keuangan sebagai bagian dari pengelolaan suatu bisnis (Trombetta, 2016). Sikap terhadap perilaku mengacu pada sejauhmana seseorang memiliki evaluasi yang mendukung atau tidak mendukung atau penilaian terhadap perilaku yang bersangkutan (Ajzen, 1991). Belum ada penelitian sebelumnya mengenai hal ini, akan tetapi ada temuan yang menunjukkan bahwa semakin tinggi tingkat literasi keuangan, semakin besar kecenderungan untuk menciptakan usaha baru (Singrhy dan Bogoro, 2016). Berdasarkan temuan tersebut mengingat bahwa literasi akuntansi juga cukup penting, maka semakin baik tingkat literasi akuntansi seseorang semakin baik juga kecenderungan sikap seseorang dalam menciptakan usaha baru. Berdasarkan uraian di atas maka hipotesis dalam penelitian ini adalah:

H7 : Literasi akuntansi berpengaruh terhadap sikap pada penciptaan usaha baru

\section{Pengaruh Sikap pada Penciptaan Usaha Baru terhadap Niat Berwirausaha}

Sikap terhadap perilaku mengacu pada sejauhmana seseorang memiliki evaluasi yang mendukung atau tidak mendukung atau penilaian terhadap perilaku yang bersangkutan (Ajzen, 1991). Niat berwirausaha dapat didefinisikan sebagai keinginan atau tekad individu untuk memulai bisnis baru untuk mengeksploitasi peluang dan risiko bisnis melalui pembelajaran kewiraswastaan (Utami, 2017). Belum ada penelitian sebelumnya mengenai hal ini, akan tetapi munculnya niat berwirausaha didasarkan dari sikap seseorang untuk terjun memulai usaha baru (Bustarosa, 2018). Berdasarkan uraian di atas maka hipotesis dalam penelitian ini adalah :

H8: Sikap pada penciptaan usaha baru berpengaruh terhadap niat berwirausaha

\section{Pengaruh Literasi Akuntansi terhadap Norma Subjektif}

Literasi akuntansi merupakan pemahaman dalam menghasilkan laporan keuangan sebagai bagian dari pengelolaan suatu bisnis (Trombetta, 2016). Norma subjektif adalah keyakinan individu untuk mematuhi atau memenuhi saran atau masukan yang berasal dari orang-orang sekitar untuk turut dalam kegiatan berwirausaha (Sukmaningrum dan Rahardjo, 2017). Belum ada penelitian sebelumnya mengenai hal ini akan tetapi berdasarkan penjelasan di atas bahwa peran lingkungan sekitar seperti orang tua, teman, dan orang sekitarnya dalam membantu mendorong atau meyakinkan individu dalam memulai usaha akan cenderung lebih besar jika memiliki tingkat literasi akuntansi yang baik. Berdasarkan uraian di atas maka hipotesis dalam penelitian ini adalah : 
H9: Literasi akuntansi berpengaruh terhadap norma subjektif.

\section{Pengaruh Norma Subjektif terhadap Niat Berwirausaha}

Norma subjektif adalah keyakinan individu untuk mematuhi atau memenuhi saran atau masukan yang berasal dari orang-orang sekitar untuk turut dalam kegiatan berwirausaha (Sukmaningrum dan Rahardjo, 2017). Niat berwirausaha dapat didefinisikan sebagai keinginan atau tekad individu untuk memulai bisnis baru untuk mengeksploitasi peluang dan risiko bisnis melalui pembelajaran kewiraswastaan (Utami, 2017). Belum ada penelitian sebelumnya mengenai hal ini, akan tetapi berdasarkan penjelasan sebelumnya dapat dikatakan bahwa semakin baik masukan atau saran dari orang sekitar untuk berwirausaha maka niat seseorang untuk melakukan perilaku tersebut cenderung kuat. Berdasarkan uraian di atas maka hipotesis dalam penelitian ini adalah :

H10 : Norma subjektif berpengaruh terhadap niat berwirausaha.

\section{Pengaruh Literasi Akuntansi terhadap Persepsi Kontrol Perilaku}

Literasi akuntansi merupakan pemahaman dalam menghasilkan laporan keuangan sebagai bagian dari pengelolaan suatu bisnis (Trombetta, 2016). Persepsi kontrol perilaku (perceived behavioral control) adalah kontrol perilaku yang dirasakan mengenai kemudahan dan/atau kesulitan untuk melakukan perilaku tertentu (Ajzen, 1991). Belum ada penelitian sebelumnya mengenai hal ini, akan tetapi berdasarkan penjelasan tersebut bahwa seseorang yang memiliki tingkat literasi akuntansi yang baik akan cenderung merasakan bahwa hal tersebut dapat mempermudah dirinya dalam mewujudkan niatnya untuk berwirausaha. Berdasarkan uraian di atas maka hipotesis dalam penelitian ini adalah :

H11 : Literasi akuntansi berpengaruh terhadap persepsi kontrol perilaku

\section{Pengaruh Persepsi Kontrol Perilaku terhadap Niat Berwirausaha}

Persepsi kontrol perilaku (perceived behavioral control) adalah kontrol perilaku yang dirasakan mengenai kemudahan dan/atau kesulitan untuk melakukan perilaku tertentu (Ajzen, 1991). Niat berwirausaha dapat didefinisikan sebagai keinginan atau tekad individu untuk memulai bisnis baru untuk mengeksploitasi peluang dan risiko bisnis melalui pembelajaran kewiraswastaan (Utami, 2017). Berdasarkan penjelasan tersebut dapat dikatakan bahwa semakin baik seseorang dalam merasakan hal-hal yang dapat mempermudah atau mempersulit dalam melakukan suatu perilaku, maka akan cenderung memiliki niat yang semakin besar. Berdasarkan uraian di atas maka hipotesis dalam penelitian ini adalah :

H12 : Persepsi kontrol perilaku
berpengaruh terhadap niat
berwirausaha

\section{METODOLOGI PENELITIAN}

Jenis data yang digunakan dalam penelitian ini adalah data 
kuantitatif, sumber data yang digunakan yaitu data primer, dan teknik pengumpulan data yang digunakan adalah kuesioner. Populasi pada penelitian ini yaitu mahasiswa aktif program studi akuntansi STIE Sutaatmadja sebanyak 215 mahasiswa yang terdiri dari semester 2 hingga semester 8 dengan teknik pengambilan sampel menggunakan metode simple random sampling. Pengambilan jumlah sampel dalam penelitian ini mengacu pada Betler \& Chou (1987) dalam Latan (2012) yang merekomendasikan jumlah sampel yang harus dipenuhi untuk estimasi SEM adalah 5 kali jumlah variabel teramati. Jumlah variabel teramati dalam penelitian ini yaitu sebanyak 30 , sehingga yang menjadi sampel dalam penelitian ini yaitu sebanyak 150 .

Variabel penelitian dalam penelitian ini disebut variabel laten yaitu variabel yang tidak dapat diukur secara langsung dan memerlukan beberapa indikator sebagai proksi (Ghozali dan Fuad, 2014). Dalam penelitian ini, peneliti menggunakan istilah variabel laten eksogen untuk variabel independen (bebas). Variabel laten eksogen dalam penelitian ini yaitu literasi keuangan (financial literacy) dan literasi akuntansi (accounting literacy). Sedangkan untuk variabel laten dependen (terikat) peneliti menggunakan istilah variabel laten endogen. Variabel laten endogen tersebut dalam penelitian ini yaitu sikap pada penciptaan usaha baru (attitude toward new venture creation), norma subjektif (subjective norm), persepsi kontrol perilaku (perceived behavioral control) dan niat berwirausaha (entrepreneurial intention).

\section{HASIL DAN PEMBAHASAN}

\section{Deskriptif Responden Kuesioner}

$150 \begin{gathered}\text { Karakteristik responden dari } \\ \text { responden yang mengisi }\end{gathered}$ kuesioner penelitian ini adalah sebagai berikut :

\section{Tabel 2}

Deskriptif Responden Kuesioner Berdasarkan Jenis Kelamin

\begin{tabular}{|l|l|l|}
\hline $\begin{array}{l}\text { Berdasark } \\
\text { an Jenis } \\
\text { Kelamin }\end{array}$ & $\begin{array}{l}\text { Jumlah } \\
\text { Respond } \\
\text { en }\end{array}$ & $\begin{array}{l}\text { Persenta } \\
\text { se }\end{array}$ \\
\hline Laki-Laki & 30 & $20 \%$ \\
\hline Perempuan & 120 & $80 \%$ \\
\hline Jumlah & 150 & $100 \%$ \\
\hline \multicolumn{3}{|c|}{ Sumber: data primer yang } \\
diolah (2018)
\end{tabular}

Tabel 3

Deskriptif Responden Kuesioner Berdasarkan Semester

\begin{tabular}{|c|c|c|}
\hline $\begin{array}{l}\text { Berdasark } \\
\text { an } \\
\text { Semester }\end{array}$ & \begin{tabular}{|l|} 
Jumlah \\
Respond \\
en
\end{tabular} & $\begin{array}{l}\text { Persenta } \\
\text { se }\end{array}$ \\
\hline 2 (Dua) & 41 & $27.33 \%$ \\
\hline 4 (Empat) & 58 & $38.67 \%$ \\
\hline 6 (Enam) & 31 & $20.67 \%$ \\
\hline 8 (Delapan) & 20 & $13.33 \%$ \\
\hline Jumlah & 150 & $100 \%$ \\
\hline
\end{tabular}

Asumsi-Asumsi dalam LISREL

Menurut Ghozali dan Fuad
(2014) asumsi-asumsi yang
"seharusnya" dipenuhi dalam LISREL
adalah sebagai beikut : 1. Normalitas

Normalitas merupakan bentuk suatu distribusi data pada suatu variabel metric tunggal dalam menghasilkan distribusi normal (Hair, 1998) dalam (Ghozali dan Fuad, 2014). 
Normalitas bagi menjadi dua yaitu univariate normality (normalitas univariate) dan multivariate normality (normalitas multivariate). Suatu data dikatakan normal jika secara univariate dan multivariate mempunyai $P$-Value $>$ 0.05 (Latan, 2012). Dalam penelitian ini uji normalitas dilakukan dengan menggunakan program LISREL dan didapat bahwa secara univariate maupun multivariate $P$-Value untuk skewness dan kurtosis $<0.05$, sehingga data pada penelitian ini tidak normal.

\section{Multikoleniaritas}

\section{(Multicollinearity)}

Multicollinearity bukanlah suatu permasalahan ada atau tidaknya, melainkan seberapa besar tingkat keberadaannya. Nilai VIF yang lebih tinggi dari 10 mengindikasikan masalah multicollinearuty yang berpotensi membahayakan (Adnan, Ahmad, \& Adnan, 2006; Bowen \& Guo, 2011; Kline R.B, 2005; Hair, Black, Babin, \& Anderson, 2009; Steven, 2009; Fiona, 2012) dalam (Rasyid, 2013). Uji multicollinearity dalam penelitian ini menggunakan program SPSS dan dari hasil keluarannya didapat bahwa semua nilai VIF untuk seluruh percobaan pada setiap variabel teramati bernilai lebih kecil dari 10. Maka dari itu dapat disimpulkan bahwa data penelitian ini bebas dari multicollinearity.

\section{Penerapan SEM}

Langkah-langkah dalam penerapan SEM, adalah sebagai berikut :

\section{Spesifikasi Model}

Tahap ini berkaitan dengan pembentukan model awal persamaan struktural. Model awal ini diformulasikan berdasarkan suatu teori atau penelitian sebelumnya. Dalam penelitian ini terdapat 2 variabel laten eksogen yaitu literasi keuangan dan literasi akuntansi, sedangkan variabel laten endogen terdapat 4 variabel yaitu sikap pada penciptaan usaha baru, norma subjektif, persepsi kontrol perilaku dan niat berwirausaha. Berdasarkan 6 variabel laten tersebut, didapat variabel teramati (observed variable) sebanyak 30 buah.

\section{Identifikasi Model}

Langkah selanjutnya setelah spesifikasi model yaitu identifikasi model yang dilakukan untuk mengetahui unik tidaknya dari model yang telah dibangun dengan data empiris yang dikumpulkan melalui kuesioner sehingga model tersebut dapat diestimasi. Hasil output LISREL didapat bahwa degree of freedom nya sebesar 395, sehingga model pada penelitian ini teridentifikasi sebagai over-identified model.

\section{Estimasi Model}

Estimasi model digunakan untuk memperoleh nilai-nilai dari parameter-parameter yang ada didalam model. Model estimasi yang digunakan dalam penelitian ini yaitu Maximum Likelihood karena metode ini banyak digunakan peneliti dalam SEM pada saat ini (Wijanto, 2008) dalam (Rasyid, 2013).

Penjelasan sebelumnya diketahui bahwa data dalam penlitian ini adalah tidak normal. Untuk mengatasi hal tersebut maka dapat dilakukan dengan menggunakan asymptotic covariance matrix (Latan, 2012). 


\section{a. Pengujian Estimasi Model-1} Penelitian

Model awal ini dianalisis dengan berfokus pada hasil uji model berupa output dari LISREL. Berdasarkan analisis terhadap model awal ini, diketahui bahwa :

1). Tidak terdapat error variance yang bernilai negatif pada semua variabel teramati.

2). Terdapat beberapa variabel teramati yang memiliki nilai SLF $<0.3$, yaitu :

- LK1 dengan SLF sebesar 0.29

- LK2 dengan SLF sebesar 0.04

3). Analisis terhadap T-Value terdapat beberapa hubungan antar variabel laten memiliki nilai $t<1.96$, diantaranya :

- Antara FINLIT dan ATNVC, dengan nilai $t=0.45$

- Antara FINLIT dan SUBJNORMS, dengan nilai $\mathrm{t}$ $=0.45$

- Antara FINLIT dan PBC, dengan nilai $\mathrm{t}=0.45$

- Antara ACCLIT dan ATNVC, dengan nilai $t=-0.43$

- Antara ACCLIT dan SUBJNORMS, dengan nilai $t$ $=-0.44$

- Antara ACCLIT dan PBC, dengan nilai $t=-0.44$

- Antara SUBJNORMS dan El, dengan nilai $\mathrm{t}=0.46$

Kesimpulan yang didapat dari analisis di atas bahwa model awal penelitian yang dibangun masih belum baik karena dari 12 hubungan antar variabel laten, LISREL hanya mengakui 9 hubungan antar variabel dan masih terdapat variabel teramati dengan nilai SLF $<0.3$ serta nilai $\mathrm{t}<1.96$. Maka dari itu peneliti melakukan pemodelan ulang dengan menghilangkan variabel teramati LK1 dan LK2 serta menghilangkan hubungan antara variabel laten FINLIT dan ATNVC, FINLIT dan SUBJNORMS, FINLIT dan PBC, ACCLIT dan ATNVC, ACCLIT dan SUBJNORMS, ACCLIT dan PBC, serta SUBJNORMS dan El.

\section{b. Pengujian Estimasi Model-2} Penelitian

Langkah yang dianalisis sama halnya dengan langkah analisis sebelumnya pada model awal.

\section{1). Identifikasi Model-2}

Hasil output LISREL pada model-2 didapat bahwa degree of freedom nya sebesar 62, sehingga model-2 pada penelitian ini teridentifikasi sebagai over-identified model.

2). Hasil Uji Estimasi Model-2 Berdasarkan analisis terhadap model-2 ini, didapat hasil bahwa

- Tidak terdapat error variance yang bernilai negatif pada semua variabel teramati.

- Tidak terdapat variabel teramati yang memiliki nilai SLF $<0.3$.

- Analisis terhadap T-Value diketahui bahwa tidak terdapat hubungan antar variabel yang memiliki nilai $\mathrm{t}<$ 1.96.

Berdasarkan pengujian model-2 di atas, peneliti menyimpulkan bahwa model-2 dikatakan baik jika dilihat dari nilai error variance, standardized solution, dan $t$-value. 


\section{Uji Kecocokan Model}

Pengujian ini dilakukan untuk mendapatkan goodness of fit, reliabilitas, validitas, dan signifikansi dari model-2 penelitian.

\section{Respesifikasi Model}

Respesifikasi model perlu dilakukan jika setelah dilakukan penilaian goodness of fit model penelitian tidak fit dan dalam proses pelaksanaannya harus didukung dengan teori (Latan, 2012). Berdasarkan serangkaian pengujian yang ditelah dilakukan, didapat bahwa bahwa model-2 penelitian dikatakan sudah fit karena model tersebut sudah memenuhi kriteria baik setelah di uji kecocokan model, sehingga tidak perlu dilakukan respesifikasi model.

\section{Pembahasan}

Berdasarkan serangkaian pengujian yang telah dilakukan bahwa model-2 merupakan model penelitian yang fit dengan menyisakan 13 variabel teramati dan 2 hubugan antar variabel laten. Hasil pengujian estimasi mengharuskan 2 variabel teramati yaitu LK1 dan LK2 dikeluarkan dari model penelitian karena memiliki nilai SLF $<0.3$, kemudian 7 hubungan antar variabel laten yaitu FINLIT - ATNVC, FINLIT - SUBJNORMS, FINLIT PBC, ACCLIT - ATNVC, ACCLIT SUBJNORMS, ACCLIT - PBC dan SUBJNORMS - El harus dikeluarkan dari model karena nilai $t<1.96$. Kemudian dari hasil uji validitas dan reliabilitas didapat bahwa dari 13 variabel teramati dengan 3 variabel laten tersebut memiliki tingkat validitas dan reliabilitas yang baik.

\section{Hasil Pengujian Hipotesis}

Berdasarkan analisis model struktural, didapat bahwa 4 hipotesis diterima dari 12 hipotesis yang diajukan dalam penelitian ini.

\section{Hipotesis 1 : Literasi \\ Keuangan berpengaruh terhadap Sikap pada Penciptaan Usaha Baru}

Hasil pengujian hipotesis 1 yaitu bahwa hubungan antara variabel FINLIT dan ATNVC memiliki nilai $t$ sebesar 0.45 yang artinya < 1.96 sehingga hipotesis 1 ditolak. Hal ini dapat dikatakan bahwa literasi keuangan tidak berpengaruh terhadap sikap pada penciptaan usaha baru. Sikap terhadap perilaku mengacu pada sejauhmana seseorang memiliki evaluasi yang mendukung atau tidak mendukung atau penilaian terhadap perilaku yang bersangkutan (Ajzen, 1991). Tingkat literasi keuangan seseorang mau tinggi atau pun rendah tidak ada pengaruhnya terhadap orang tersebut dalam melakukan suatu perilaku dimana perilaku disini yaitu suatu sikap dalam menciptakan suatu usaha baru yang artinya mengabaikan konsekuensi yang akan didapat jika tidak memiliki tingkat literasi keuangan yang baik atau dengan kata lain bahwa literasi keuangan tidak mendukung dalam sikap seseorang pada penciptaan usaha baru. Hasil ini tidak sejalan dengan temuan Singrhy dan Bogoro (2016) yang menunjukkan bahwa semakin tinggi tingkat literasi keuangan, semakin besar kecenderungan untuk menciptakan perusahaan baru.

Hipotesis 2 : Sikap pada 


\section{berpengaruh terhadap Niat Berwirausaha}

Hasil pengujian hipotesis 2 dapat dilihat pada tabel 10 yaitu bahwa hubungan antara variabel ATNVC dan El memiliki nilai $t$ sebesar 3.21 yang artinya $>1.96$ sehingga hipotesis 2 diterima. Dengan demikian hal ini dapat dikatakan bahwa ATNVC berpengaruh terhadap El. Hal ini didukung dengan hasil penelitian yang dilakukan oleh Shingry dan Bogoro (2016) yang menunjukkan bahwa sikap pada penciptaan usaha baru berhubungan secara signifikan dengan graduated entrepreneurial intention. Hal ini mengindikasikan semakin tinggi ketertarikan untuk memanfaatkan peluang usaha baru semakin meningkat pula niat berwirausaha, semakin berpandangan positif terhadap kegagalan usaha yang dialami semakin meningkat niat berwirausaha serta semakin berani mengambil risiko apapun yang datang semakin meningkat pula niat berwirausaha (Cruz et al, 2015).

\section{Hipotesis 3 : Literasi Keuangan berpengaruh terhadap Norma Subjektif}

Hasil pengujian hipotesis 3 yaitu bahwa hubungan antara variabel FINLIT dan SUBJNORMS memiliki nilai t sebesar 0.45 yang artinya $<1.96$ sehingga hipotesis 3 ditolak. Hal ini dapat dikatakan bahwa literasi keuangan tidak berpengaruh terhadap norma subjektif. Norma subjektif adalah pandangan atau pengaruh yang diberikan pihak luar kepada individu (Sumaryono, 2016). Orangorang sekitar (orang tua, teman, orang penting lainnya) akan tetap mendukung jika orang terdekatnya memiliki niat untuk berwirausaha meskipun orang tersebut tidak memiliki tingkat literasi keuangan yang baik.

\section{Hipotesis 4 : $\quad$ Norma Subjektif berpengaruh terhadap Niat Berwirausaha}

Hasil pengujian hipotesis 4 yaitu bahwa hubungan antara variabel SUBJNORMS dan El memiliki nilai $t$ sebesar 0.46 yang artinya < 1.96 sehingga hipotesis 4 ditolak. Hal ini dapat dikatakan bahwa norma subjekif tidak berpengaruh terhadap niat berwirausaha. Norma subjektif adalah pandangan atau pengaruh yang diberikan pihak luar kepada individu (Sumaryono, 2016). Niat seseorang dalam berwirausaha tidak akan berubah menjadi lebih kuat ketika ada pengaruh dari orang sekitar dan tidak akan menjadi lemah ketika tidak ada pengaruh orang sekitar.

\section{Hipotesis 5 : $\quad$ Literasi Keuangan
berpengaruh
Persepsi
Perilaku}

Hasil pengujian hipotesis 5 yaitu bahwa hubungan antara variabel FINLIT dan PBC memiliki nilai $t$ sebesar 0.45 yang artinya < 1.96 sehingga hipotesis 5 ditolak. Persepsi kontrol perilaku merupakan kontrol perilaku yang dirasakan mengenai kemudahan dan/atau kesulitan untuk melakukan perilaku tertentu (Ajzen, 1991). Berdasarkan hal tersebut bahwa literasi keuangan tidak dijadikan atau tidak diyakini sebagai faktor yang 
dapat mempermudah atau mempersulit dari seseorang untuk melakukan suatu perilaku.

\section{Hipotesis 6 : Persepsi Kontrol Perilaku berpengaruh terhadap Niat Berwirausaha}

Hasil pengujian hipotesis 6 dapat dilihat pada tabel 10. Pada tabel tersebut terlihat bahwa hubungan antara variabel PBC dan El memiliki nilai t sebesar 5.13 yang artinya $>1.96$ sehingga hipotesis 6 diterima. Dengan demikian hal ini dapat dikatakan bahwa PBC berpengaruh terhadap El. Persepsi kontrol perilaku merupakan kontrol perilaku yang dirasakan mengenai kemudahan dan/atau kesulitan untuk melakukan perilaku tertentu (Ajzen, 1991). Semakin baik kendali seseorang dalam merasakan hal-hal yang dapat mempermudah atau mempersulit dalam melaksanakan usaha, maka semakin meningkat niat seseorang tersebut dalam berwirausaha. Hal ini didukung dengan hasil penelitian yang dilakukan oleh Singhry dan Bogoro (2016) yang menemukan adanya hubungan positif dan signifikan antara perceived behavioral control dan graduated entrepreneurial intention.

\section{Hipotesis 7 : $\quad$ Literasi \\ Akuntansi berpengaruh terhadap Sikap pada Penciptaan Usaha Baru}

Hasil pengujian hipotesis 7 yaitu bahwa hubungan antara variabel ACCLIT dan ATNVC memiliki nilai $t$ sebesar -0.43 yang artinya $<1.96$ sehingga hipotesis 7 ditolak. Sikap terhadap perilaku mengacu pada sejauhmana seseorang memiliki evaluasi yang mendukung atau tidak mendukung atau penilaian terhadap perilaku yang bersangkutan (Ajzen, 1991). Berdasarkan hal tersebut menandakan bahwa literasi akuntansi tidak dijadikan sebagai faktor yang dapat mempermudah atau mempersulit seseorang dalam sikap pada penciptaan usaha baru.

\section{Hipotesis 8 : Sikap pada Penciptaan Usaha Baru berpengaruh terhadap Niat Berwirausaha}

Hasil pengujian hipotesis 8 dapat dilihat pada tabel 10. Pada tabel tersebut terlihat bahwa hubungan antara variabel ATNVC dan EI memiliki nilai t sebesar 3.21 yang artinya $>1.96$ sehingga hipotesis 8 diterima. Dengan demikian hal ini dapat dikatakan bahwa ATNVC berpengaruh terhadap El. Hal ini mengindikasikan semakin tinggi ketertarikan untuk memanfaatkan peluang usaha baru semakin meningkat pula niat berwirausaha, semakin berpandangan positif terhadap kegagalan usaha yang dialami semakin meningkat niat berwirausaha serta semakin berani mengambil risiko apapun yang datang semakin meningkat pula niat berwirausaha oleh mahasiswa fakultas ekonomi (Cruz et al, 2015).

\section{Hipotesis 9 : Literasi \\ Akuntansi berpengaruh terhadap Norma Subjektif}

Hasil pengujian hipotesis 9 yaitu bahwa hubungan antara variabel 
ACCLIT dan SUBJNORMS memiliki nilai t sebesar -0.44 yang artinya $<1.96$ sehingga hipotesis 9 ditolak. Hal ini dapat dikatakan bahwa literasi akuntansi tidak berpengaruh terhadap norma subjektif. Norma subjektif adalah pandangan atau pengaruh yang diberikan pihak luar kepada individu (Sumaryono, 2016). Tinggi rendahnya tingkat literasi akuntansi seseorang tidak akan merubah bentuk dukungan atau pengaruh orang sekitar.

\section{Hipotesis 10 : Norma Subjektif terhadap Niat Berwirausaha}

Hasil pengujian hipotesis 10 yaitu bahwa hubungan antara variabel SUBJNORMS dan El memiliki nilai $t$ sebesar 0.46 yang artinya < 1.96 sehingga hipotesis 10 ditolak. Hal ini dapat dikatakan bahwa norma subjektif tidak berpengaruh terhadap niat berwirausaha. Norma subjektif adalah pandangan atau pengaruh yang diberikan pihak luar kepada individu (Sumaryono, 2016). Ada tidaknya dukungan dari orang sekitar tidak menjadikan niat seseoang dalam berwirausaha menjadi lebih kuat atau tidak.

\section{Hipotesis 11 : Literasi

Akuntansi
berpengaruh
Persepsi
Perilaku

Hasil pengujian hipotesis 11 yaitu bahwa hubungan antara variabel ACCLIT dan PBC memiliki nilai $t$ sebesar -0.44 yang artinya $<1.96$ sehingga hipotesis 11 ditolak. Persepsi kontrol perilaku merupakan kontrol perilaku yang dirasakan mengenai kemudahan dan/atau kesulitan untuk melakukan perilaku tertentu (Ajzen, 1991). Berdasarkan hal tersebut bahwa tinggi rendahnya literasi akuntansi seseorang tidak menjadikan kendali seseorang menjadi lebih baik atau lebih buruk dalam melakukan suatu perilaku.

\section{Hipotesis 12 : $\quad$ Persepsi Kontrol Perilaku berpengaruh terhadap Niat Berwirausaha}

Hasil pengujian hipotesis 12 dapat dilihat pada tabel 10. Pada tabel tersebut terlihat bahwa hubungan antara variabel PBC dan El memiliki nilai t sebesar 5.13 yang artinya $>1.96$ sehingga hipotesis 12 diterima. Dengan demikian hal ini dapat dikatakan bahwa PBC berpengaruh terhadap El. Persepsi kontrol perilaku merupakan kontrol perilaku yang dirasakan mengenai kemudahan dan/atau kesulitan untuk melakukan perilaku tertentu (Ajzen, 1991). Semakin baik kendali seseorang dalam merasakan hal-hal yang dapat mendorong atau menghambat dalam melaksanakan usaha, maka semakin meningkat niat seseorang tersebut dalam berwirausaha.

\section{KESIMPULAN}

Berdasarkan hasil pengujian yang telah dilakukan didapat bahwa literasi keuangan dan literasi akuntansi tidak berpengaruh terhadap sikap pada penciptaan usaha baru, norma subjektif, dan persepsi kontrol perilaku pada mahasiswa akuntansi STIE 
Sutaatmadja. Kemudian norma subjektif tidak berpengaruh terhadap niat berwirausaha pada mahasiswa akuntansi STIE Sutaatmadja. Sedangkan sikap pada penciptaan usaha baru dan persepsi kontrol perilaku berpengaruh terhadap niat berwirausaha pada mahasiswa akuntansi STIE Sutaatmadja.

Berdasarkan hasil penelitian yang telah diuraikan, maka saran yang diajukan peneliti adalah sebagai berikut :

1. Penelitian selanjutnya untuk meneliti kembali penelitian ini dengan sampel di uiversitas lain, SMA/SMK, atau bahkan masyarakat yang berniat untuk berwirausaha karena penelitian ini masih tergolong baru dan dapat menambahkan variabel lain diluar penelitian ini serta mencari teori lain yang secara langsung ke variabel depedent.

2. Mahasiswa yang memiliki niat untuk berwirausaha disarankan untuk memiliki tingkat literasi keuangan dan literasi akuntansi yang baik, walaupun sikap pada penciptaan usaha baru dan persepsi kontrol perilaku lebih diutamakan.

\section{REFERENCES}

\section{Buku}

Ghozali, Imam \& Fuad. 2014. Structural Equation Modeling Teori, Konsep dan Aplikasi dengan Program LISREL 9.10. Badan Penerbit Universitas Diponegoro.

Latan, Hengky. 2012. Stuctural Equation Modeling Konsep dan Aplikasi Menggunakan Program
LISREL 8.80. Bandung:

Alfabeta.

Narimawati, Umi dan Jonathan Sarwono. 2017. Structural Equation Modeling (SEM) Berbasis Kovarian dengan LISREL dan AMOS untuk Riset Skripsi, Tesis, dan Disertasi. Jakarta: Salemba Empat.

\section{Jurnal , Skripsi dan Tesis}

Ajzen, Icek. 1985. Behavioral Interventions Based on the Theory of Planned Behavior.

Ajzen, Icek. 1991. The Theory of Planned Behavior. Organizational Behavior and Human Decision Processes 50, 179-211.

Ajzen, Icek. 2001. Nature and Operation of Attitudes. Universitas of Massachusetts.

Armitage, C.J. \& Conner, M. 2001. Efficacy of the theory of planned behavior: A meta-analytic review. British Journal of Social Psychology, 40, 471-499.

Azwar, Budi. 2013. Analisis FaktorFaktor yang Mempengaruhi Niat Kewirausahaan

(Entrepreneurial Intention) (Studi Terhadap Mahasiswa Universitas Islam Negeri SUSKA Riau). Menara, Vol. 12 No. 1 Januari - Juni 2013.

Bustarosa, Dafista Fidel. 2018. Peran Sikap, Norma Subjektif, Kontrol Perilaku, dan Pendidikan Kewirausahaan dalam Menumbuhkan Minat Berwirausaha Mahasiswa di Perguruan Tinggi Negeri dan Perguruan Tinggi Swasta. Bandar Lampung: Universitas Lampung. 
Cruz, Leonel da, Ni Wayan Sri Suprapti \& Ni Nyoman Kerti Yasa. 2015. Aplikasi Theory of Planned Behavior dalam Membangkitkan Niat Berwirausaha Bagi Mahasiswa Fakultas Ekonomi Unpaz, Dili Timor Leste. EJurnal Ekonomi dan Bisnis Universitas Udayana 4.12 (2015): 895-920 ISSN: 23373067. Universitas Udayana.

Dahmen, Pearl dan Eileen Rodríguez. 2014. Financial Literacy and the Success of Small Businesses: An Observation from a Small Business Development Center. Article 3 Volume 7, Issue 1. University of South Florida.

Deri, Erri Nugraha, I Wayan Santika \& I G A K Giantari. 2016. Niat Berwirausaha Dikalangan Mahasiswa (Studi:Mahasiswa Program Reguler Fakultas Ekonomi Dan Bisnis Universitas Udayana). E-Jurnal Manajemen Unud, Vol. 5, No. 2, 2016: 9851013 ISSN : 2302-8912.

Elson, Raymond J dkk. 2013. The Meta Language of Accounting: What's The Level Of Students' Understanding?. Journal Of Instructional Pedagogies.

Laily, Nujmatul. 2016. Pengaruh Literasi Keuangan Terhadap Perilaku Mahasiswa Dalam Mengelola Keuangan. Universitas Negeri Malang

M.G. Wi Endang Np. 2012. Analisis Faktor-Faktor Motivasi Berwirausaha Terhadap Keberhasilan Pengusaha Ukm (Studi Pada Ukm Kota Malang).
Jurnal Profit, Volume 6, Nomor 1, Juni 2012.

Nurfaizana, Della Rulita \& Endah Andayani. 2017. Pengaruh Manajemen Keuangan Pribadi dan Efikasi Diri Terhadap Intensi Berwirausaha Mahasiswa Pendidikan Ekonomi. Seminar Nasional \& Call For Paper, FEB Unikama "Peningkatan Ketahanan Ekonomi Nasional Dalam Rangka Menghadapi Persaingan Global" Malang, 17 Mei.

Oseifuah, Emmanuel Koso. 2010. Financial Literacy and Youth Entrepreneurship in South Africa. DOI: 10.1108/20400701011073473

Rahayu, Apristi Yani \& Musdholifah. 2017. Pengaruh Literasi Keuangan Terhadap Kinerja dan KEberlanjutan UMKM di Kota Surabaya. Jurnal IImu MAnajmen Volume 5 Nomor 3.

Ramayah, T \& Zainon Harun. 2005. Entrepreneurial Intention Among University Sains Malaysia (USM) Students.

Rasyid, Hainur. 2013. Analisis FaktorFakor Yang Mempengaruhi Kesuksesan Implementasi EGovernment: Studi Kasus Sistem Informasi dan Komputerisasi Haji Terpadu (SISKOHAT). Jakarta: Universitas Indonesia.

Sari, Anggun Kembar. 2013. Analisis Pengaruh Tingkat Pendidikan, Pertumbuhan Ekonomi, Dan Upah Terhadap Pengangguran Terdidik Di Sumatera Barat. 
Jurnal Ekonomi Pembangunan Fakultas Ekonomi Universitas Negeri Padang.

Singhry, Hassan Barau \& Patrick Bogoro. 2016. Financial Literacy And Entrepreneurial Intention Of Generation " $Y$ " Graduates: An Analysis Based On The Theory Of Planned Behavior

Sukmaningrum, Swastinitya \& Mudji Rahardjo. 2017. Faktor-Faktor Yang Mempengaruhi Niat Berwirausaha Mahasiswa Menggunakan Theory of Planned Behavior (Studi Pada Mahasiswa Pelaku Wirausaha Fakultas Ekonomika Dan Bisnis Universitas Diponegoro.

Fakultas Ekonomika dan Bisnis Universitas Diponegoro Semarang.

Sumaryono. 2016. Pengujian Pengaruh Theory Of Planned Behavior Dan Tingkat Pemahaman Mengenai Chartered Accountant Terhadap Niat Mahasiswa Untuk Mengambil Sertifikasi Chartered Accountant (Studi Kasus Pada Mahasiswa Akuntansi Angkatan 2012 Dan 2013 Universitas Negeri Yogyakarta).

Thompson, Edmund R. 2009. Individual Entrepreneurial Intent: Construct Clarification And Development of An Internationally Reliable Metric.

Trombetta, Marco. 2016. Accounting And Finance Literacy And SelfEmployment: An Exploratory Study.

Utami, Christina Whidya. 2017. Attitude, Subjective Norms, Perceived Behavior,
Entrepreneurship Education and Self-efficacy toward Entrepreneurial Inrention University Student in Indonesia. European Research Studies Journal Volume XX, Issue 2A, 2017.

Wahyono, Budi, Siswandari \& Djoko Santosa. 2015. Pengaruh Pendidikan Kewirausahaan Terhadap Niat Berwirausaha Siswa Smk Negeri 1 Pedan Tahun 2013.

Walipah dan Naim. 2016. Faktor Faktor Yang Mempengaruhi Niat Berwirausaha Mahasiswa. Jurnal Ekonomi Modernisasi http://ejournal.unikama.ac.id/ind ex.php/JEKO JEM 12,3 (2016) 138-144

Wijaya, Tony. 2008. Kajian Model Empiris Perilaku Berwirausaha UKM DIY dan Jawa Tengah. Jurnal Manajemen dan Kewirausahaan, Vo. 10 No. 2, September 2008: 93-104.

\section{Berita dan Artikel}

http://edukasi.rakyatku.com/read/8325 5/2018/01/19/ciptakanwirausaha-stie-nobel-danhipmi-sulsel-goes-to-school (diakses pada tanggal 30 Januari 2018 pukul 10.58 WIB) 